\title{
A Review of the Vulnerable Group Development (VGD) Program for Protection and Promotion of Poor Households in Bangladesh
}

\author{
Mohammad Abdul Hannan Pradhan ${ }^{1,2, *}$, Jamalludin Sulaiman ${ }^{1}$ \\ ${ }^{1}$ School of Social Sciences, Universiti Sains Malaysia, 11800 Penang, Malaysia \\ ${ }^{2}$ Department of Economics, Shahjalal University of Science and Technology, Sylhet, Bangladesh \\ *Corresponding Author: hannan-eco@sust.edu
}

\begin{abstract}
Social Safety Nets (SSN) is a policy instrument that is largely used for household welfare improvement and poverty reduction. Bangladesh has implemented a number of SSN program for this purpose. The Vulnerable Group Development (VGD) program is one of the current and largest SSN two-year programs that provide in-kind transfer with development programs for selected women-headed poor family. This study is an attempt to provide evidence from a micro level household survey data on whether the VGD program can provide protection and promotion effect for the beneficiary households at the end of the benefit cycle. Based on pre-intervention criterion, similar non-beneficiary households were selected as a control group. Consumption expenditure is used as a protection, while savings, productive asset and investment behaviour, child schooling are treated as promotion indicators. The Cost of Basic Needs (CBN) method is used for poverty measurement for beneficiary households. Finally, the PSM method is employed to examine the program impact on the targeted variables. The study findings provide evidence that the VGD with integrated development program have protection and promotion roles on the beneficiary household well-beings and decrease the probability being poor for the beneficiary households compared to non-beneficiary households. Extending the number of program beneficiaries and duration of benefit cycle can help reduce the poverty rate significantly.
\end{abstract}

Keywords Social Safety Net, Protection and Promotion Effect, Propensity Score Matching, Poverty Reduction

\section{Introduction}

Social safety net is a policy instrument that is largely used in developing countries for the poor and the vulnerable population. Low, Garrett, and Ginjia (1999) argued that social security or insurance program rather than SSN program cannot be suitable for resource poor country where poverty is an extensive phenomenon. The SSN measures exactly fit in the need of a wide range of the poor who require diverse assistance according to their specific conditions (Khan, Sulaiman, Ibrahim, \& Hussain Shah, 2013). Bangladesh is a large populated country where one third of its people are living below the national poverty line. Poverty and vulnerability is seen as a result of interactions among personal capacity, characteristics, and marginal situation. As every group has different causes for being poor, each set of underlying factors requires special remedial actions for poverty and vulnerability reduction (Devereux, 2002). Taking into account of these factors, the government have been making effort firmly to reduce poverty and vulnerability for the last three decades. The government has allocated around 14.75 and 13.15 percent of total budget outlay and 2.64 and 2.13 percent of GDP for Fiscal Year (FY) 2012-13 and 2013-14 respectively. As a result, the rate of poverty is decreasing rapidly (Gimenez, Ahmed, Sharif, \& Jolliffe, 2013). World Bank report published in 2013 says that during the last decade, reduction rate of poverty was 1.7 percent on an average. However, about 47 million and 26 million people still live in poverty and extreme poverty, respectively in the country (Gimenez et al., 2013).

The determinants of poverty based on income or consumption expenditure can be classified into three groups - dependency, low productivity, and vulnerability (Devereux, 2002). Bangladesh, like other countries around the world, has both economically active and inactive people. Economically inactive people depend on others for their livelihood such as other member in the household or society or state. This group of people, like the very young, disabled and the aged, are generally incapable of earnings. In Bangladesh, old dependency ratio was about 7.15 percent while young dependency ratio was 47.41 percent in 2011 . Consequently, total dependency ratio was 54.55 percent in 2011. The government have implemented SSN program for 
the older people, such as old age allowance, allowance for destitute poor women, old age home and others, for protection purpose.

Most of the active people generate their livelihood by selling their labour power because labour is their abundant asset. Lack of capacity for productive work is one of the main causes of being poor, as individuals cannot earn enough to sustain a living. Low productivity can be tackled by productivity enhancing intervention such as training. Millions of the mentally and physically sound people are either unemployed or underemployed. In addition, people are affected by idiosyncratic or natural shocks. As a result, they are trapped in low livelihood condition.

The rural women, who are not only poor and vulnerable, but also suffer from gender discrimination in many affairs. Discarded or divorced by husband is a common problem among these poor women. Divorced, discarded and single women have no social position in Bangladesh. Numbers of widowed are increasing as the women marry men older than themselves (Vlachantoni \& Falkingham, 2012).

According to Household Income Expenditure Survey (HIES) 2010, about 14.6 percent and 26.6 percent people are hardcore poor and poor who are female headed, respectively. In addition, among the poor about 33.9 percent is widowed or divorced (Bangladesh Bureau of Statistics BBS, 2010). Consequently, they become a burden to the family as well as society although they are young, and mentally and physically sound.

After independence in 1971, the government have taken several steps to improve the socio economic condition of rural poor women by implementing various programs. The VGD program is one of the current and largest SSN two-year programs that provide in-kind transfer with development programs for selected women-headed poor family who are physically and mentally sound. It is argued that in-kind transfers protect the beneficiary household from hardcore poverty in one hand. On the other hand, development training promotes their livelihood condition through productive activities. As a result, it is expected that after the benefit cycle the beneficiary household will be able to survive in a good condition without benefit. This is also an opportunity for women headed household to promote their livelihood condition persistently.

This paper offers evidence from a micro level household survey data on whether the VGD program does provide the protection and promotion effect for the targeted households at the end of the benefit cycle. Similar non-beneficiary households were selected as a control group. Consumption expenditure is used as a protection while savings, productive asset and investment behaviour, child schooling are treated as promotion indicators. The Cost of Basic Needs (CBN) method is used for poverty measurement for beneficiary households. Finally, the PSM method was employed to examine the program impact on the targeted variables.

\section{Social Safety Net: Protection and Promotion Effect}

Bangladesh allocated a modest outlay of $13.32,15.22$, 14.75 , and 13.27 percent of yearly budget for social safety net program for the financial years 2007-08, 20010-11, 2011-12, and 2012-13, respectively. Although, the allocation is relatively small when compared to major industrialized countries, it does save life when situations are terrible and can help build livelihood when the situations are less terrible (Grosh et al., 2008). SSNs have protection and promotion effect. Protection effect can be defined as an increase in household wellbeing. Rahman and Choudhury (2012) mentioned that protection effect indicates prevention of reduction into deeper poverty and the extreme hunger or chronic deficit. They considered three indicators for the protection purpose such as food security, poverty status and crisis-coping mechanism, while income, savings, access to land use and livestock as promotion indicators. The promotion effect can be treated as acquisition of productive assets, income generation activities or human quality such as child schooling (Grosh et al., 2008). With the increase of wellbeing, if the other indicators of beneficiary households such as durable goods, productive assets, investment, child schooling increases compare to control group, it can be defined as promotion effect of SSNs program.

Table 1. Social Safety Nets for Protection and Promotion

\begin{tabular}{|c|c|c|c|}
\hline \multirow{2}{*}{$\begin{array}{c}\text { Role/Objective of } \\
\text { SSN }\end{array}$} & \multicolumn{2}{|c|}{ Nature of effect } & \multirow{2}{*}{ Indicators } \\
\hline & Protection & Promotion & \\
\hline $\begin{array}{l}\text { 1.Provide transfers } \\
\text { that can } \\
\text { accomplish } \\
\text { redistribution }\end{array}$ & $\sqrt{ }$ & & $\begin{array}{l}\text { quantity and quality } \\
\text { of food consumption }\end{array}$ \\
\hline $\begin{array}{c}\text { 2. Enable } \\
\text { households to } \\
\text { make better } \\
\text { investment in their } \\
\text { future }\end{array}$ & & $\sqrt{ }$ & $\begin{array}{c}\text { acquisition of } \\
\text { productive assets, } \\
\text { income generation } \\
\text { activities or human } \\
\text { quality such as child } \\
\text { schooling }\end{array}$ \\
\hline \multicolumn{4}{|l|}{$\begin{array}{l}\text { 3.Help households } \\
\text { manage risks }\end{array}$} \\
\hline $\begin{array}{c}\text { Avoid irreversible } \\
\text { losses } \\
\end{array}$ & $\sqrt{ }$ & & \\
\hline $\begin{array}{l}\text { Allow higher } \\
\text { risk/return } \\
\text { activities }\end{array}$ & & $\sqrt{ }$ & \\
\hline $\begin{array}{l}\text { 4. Help government } \\
\text { make sound } \\
\text { choices }\end{array}$ & $\sqrt{ }$ & $\sqrt{ }$ & Growth rate, \\
\hline
\end{tabular}

Source: Grosh et al.(2008)

The quantity and quality of food consumption would increase through the in-kind direct transfers to households. Cash or in-kind transfers protect many poor from poverty and have also promoted a few out of poverty (Ravallion, Van de Walle, \& Gautam, 1995). Table 1 shows the various roles 
and function of SSNs program. Any income transfers can carry out the redistribution function immediately. As a result, it can play protection role resulting in increasing quantity and quality of consumption. At the same time, SSNs might enable the households to invest through acquisition of productive assets, income generation activities or human quality such as child schooling. They also facilitate sometimes to allow higher return activities. Thus, SSNs can facilitate these functions to beneficiary as protective role.

\section{Implementation of the VGD Program}

The VGD is a significant and largest safety net program for women headed poor family, which is jointly organized and implemented by Ministry of Women and Children's Affairs and Ministry of Food \& Disaster Management with the help of local NGOs. The selected women headed household receives a monthly food ration $(30 \mathrm{~kg}$ rice) over a period of 24 months cycle. Although it was introduced as a relief program in the mid-1970s, it has evolved over time to integrate food security with development objectives. Later the development package includes training on income generating activities like livestock rearing, vegetable gardening and awareness-raising on social, legal, health and nutrition issues, and basic literacy.

The main objectives of VGD program are: (1) to assist the poor rural women headed family with complementary inputs that will improve their nutrition and enhance their livelihoods and self-reliance, (2) to overcome existing food insecurity, malnutrition, lower social status and poverty so that the people can live without ultra poor condition, (3) to develop skills of women through training and encourage to collect initial capital for investment through savings, and finally (4) to increase social awareness through practical education and human development.

Program participants must meet at least four of the following criteria: (1) sever food insecurity, i.e. those household members consume less than two full meals in a day, (2) no land or less than 0.15 acres of land holding by the household, (3) very poor housing conditions, (4) it has an extremely low and irregular daily family income or casual labour, (4) it should be headed by a woman, and (5) the household has no mature male income earner. However, households fulfilling all five criteria are given priority for VGD program.

A Union Committee ${ }^{1}$ selects fifty women head household for a two year cycle every year. The committee then submits their list to the Upazilla/Thana Committee headed by Upazilla/Thana Executive Officer through the Upazilla/Than Women Affair Officer. Considering all criteria, this committee issues the VGD card by name.

\footnotetext{
${ }^{1}$ In Bangladesh, the administrative structure consists of Division, District, Thana/Upazila and Union from top to bottom level in order to size. Districts are divided into sub-district called Thana/Upazila. There are 7 divisions, 64 districts, 500 Thana/Upazila and about 4451 Unions. Every Union consists of some villages in the rural areas.
}

\section{Methodology}

\section{The Study Area}

This study was conducted in Sylhet district in Sylhet division which is located in the north east corner of Bangladesh. Sylhet division has four administrative districts. Among four districts, Sylhet district is the largest which comprises twelve Upazila and 101 unions. Total area of land is about 3,490 square kilometres where 3404 thousand people are living (BBS, 2011). Infrastructures of this district have been rapidly developing since the 2000s. These areas are well connected each other and to the other part of the country by road. Domestic works, petty trading, agricultural, off firm activities like construction, rickshaw pulling, and others are the main sources of livelihood to the poor people.

\section{Sources and Method of Data Collection}

Sample for the study was 317 households divided into two groups - the program participants and nonparticipants. The VGD program beneficiary households were selected from the 2010-2011 year cycle list which ended in December, 2012. For the comparison the non-beneficiary households control group was chosen from the same region considering pre-intervention criterion. According to the government regulation, only 50 households are selected from a union every year. However, the reason for choosing the non-beneficiary households from same region is that both groups compete for the same economic incentives and access to similar markets (Ravallion, 2007). Khandker, Koolwal, and Samad (2009) argued that to improve the precision of the propensity score, larger number nonparticipants compare to participants is needed. Jalan and Ravallion (2003) mentioned that for reliable program effects, participants and nonparticipants should be equal.

Finally, equal number of participants and nonparticipants were chosen randomly based on their availability in the house on the survey date. A structured questionnaire was administered for the both beneficiaries and non-beneficiaries households in this study. Questionnaire was designed based on the household income expenditure survey questionnaire-2005 used by Bangladesh Bureau of Statistics (BBS) including demographic characteristics, housing condition, land holding, household expenditure (food and non-food), income, savings, child schooling, risks and coping strategies. The questionnaire was pre-tested and final field survey was conducted in January and February 2013.

\section{Data Analysis}

This study applied PSM method to estimate the average treatment effect (ATT) in terms of outcome variables. The PSM method is known as nonrandomized and non-parametric approach for impact evaluation. The program administration did not conduct baseline survey on the outcome variables of interest in the study areas (only 
intervention characteristics of beneficiary). Consequently, the study relied on the PSM method to identify comparable beneficiary and non-beneficiary households using cross section data.

The PSM method is a statistical technique that provides consistent, low-bias estimates of program impact if: (1) the same data source such as same questionnaire, same time, and same interviewer are used for beneficiary and non-beneficiary, (2) beneficiary and non-beneficiary have access to same markets, and (3) limited number of observe characteristics is included (Heckman, Ichimura, \& Todd, 1998; Jalan \& Ravallion, 2003; Khandker et al., 2009).

The basic evaluation technique based on observed outcomes variables across participant and non-participant in the program, for instance per capita expenditure, $Y$ of an individual $i$ is presented as:

$$
Y_{i}=\alpha X_{i}+\beta \mathrm{T}_{i}+\mu_{i}
$$

Where, $\mathrm{T}$ is a dummy variable, which is equal to 1 for those who participate and 0 for those who do not participate in the VGD program. $X_{i}$ is the set of other observed characteristics of the household which determine the program participation. In addition, $\mu_{i}$ is an error term reflecting omitted characteristics of the household that also affect $Y$. Equation (1) notifies an approach commonly applied to evaluate the program impact, which is used to measure the direct effect of the program T on outcome $Y$. The problem with estimating equation (1) is that the providing program benefit was not random due to the following factors: a) program placement was purposive; especially for poor and vulnerable women head household and b) mean tested selection procedure was employed for beneficiary selection into the program.

It assumes that data include an observation of $Y_{i}$ for each unit $i$ in a sample of size n. Some unit received the program, VGD beneficiaries, in which case they were treated as "beneficiary" and in that case $\mathrm{T}_{i}=1$, while $\mathrm{T}_{i}=0$ when “control group", which was not VGD benefit holder. The value of $Y_{i}$ for participant is denoted $Y_{i}^{1}$ while it is $Y_{i}^{0}$ for nonparticipant or control group. If the $Y_{i}^{0}$ indicates non-participating household at the same time as a comparison benefit for participating benefits $Y_{i}^{1}$, the average treatment effect (ATE) of the program (D) could be as follows:

$$
D=E\left(Y_{i}^{1} \mid \mathrm{T}_{i}=1\right)-E\left(Y_{i}^{0} \mid \mathrm{T}_{i}=0\right)=A T E
$$

The participant and nonparticipant groups may not be the same prior to the intervention, so the expected difference between those groups may not only be due to the program intervention. Adding and subtracting the expected outcome for non-participants if they had participated in the program, the equation (2) could be as follows:

$$
\begin{gathered}
D=E\left(\mathrm{Y}_{i}^{1} \mid T_{i}=1\right)-E\left(\mathrm{Y}_{i}^{0} \mid T_{i}=0\right)+\left[E\left(Y_{i}^{0} \mid T_{i}=1\right)-E\left(Y_{i}^{0} \mid T_{i}=0\right)\right] \\
\Rightarrow D=A T E+\left[E\left(\mathrm{Y}_{i}^{0} \mid T_{i}=1\right)-E\left(\mathrm{Y}_{i}^{0} \mid T_{i}=0\right]\right. \\
\Rightarrow D=A T E+B
\end{gathered}
$$

In the equation (3), ATE is the average treatment effect, specifically the average gain in benefit of participant compared with non-participant as if non-participating household were participated. The ATE corresponds to a situation in which an arbitrarily selected household from the population was assigned to the program, so participating and non-participating households have an equal probability of receiving program benefit, $T$.

The term B in the equation (3), as $E\left(\mathrm{Y}_{i}{ }^{0} \mid T_{i}=1\right)$ is not available to estimate, the magnitude of selection bias (B) cannot be calculated. As a result, the difference in outcome between participant and non-participant could not be estimated (Khandker et al., 2009). To get rid of this biasness, PSM method is commonly used. The PSM method attempts to estimate program effect across participants and matched nonparticipant based on a range of observed characteristics (Galasso \& Ravallion, 2005). This idea was applied to find those who are observationally similar to participant in terms of characteristics. Based on the observationally similar characteristics, program participants can be matched with the nonparticipants. The mean differences in the outcome variables across the groups are compared as treatment effect. Khandker et al. (2009) mentioned that if the differences in participation and nonparticipation are based only on the differences in observered characteristics, and a larger number of nonparticipants are available to match with participants, the corresponding program impact can be estimated even if the program is not random.

In terms of many observe characteristics, two households can be similar in many dimensions or rarely similar. In PSM method, participant in the program is matched to nonparticipant based on a single propensity score. It indicates that participants are matched based on the estimated probability, or propensity score, to nonparticipants. Then ATE is calculated as the mean difference in outcomes across these two groups (Rosenbaum \& Rubin, 1983). For that reason, two basic assumptions are required to be fulfilled for credentials the program effect. First, conditional independence (CI) which states that given a set of observable covariates $\mathrm{X}$ that are not affected by program; outcomes $\mathrm{Y}$ are independent of program assignment $\mathrm{T}$. This implies that program placement is fully based on observed characteristics of the households. The region of common support (CS) or overlap is the second assumption which indicates: $0<$ $P\left(\mathrm{~T}_{i}=1 \mid \mathrm{X}_{i}\right)<1$. Heckman, LaLonde, and Smith (1999) mentioned that the $\mathrm{CS}$ condition makes sure that the participant observations have comparison observation in the distribution of propensity score. Particularly, the efficiency of the PSM technique requires a large and equal number of participant and nonparticipant observation. Hence, a considerable CS region can be found. 
If $\mathrm{CI}$ and $\mathrm{CS}$ condition are satisfied as mentioned earlier, the PSM estimator is useful to estimate ATE as mean differences in outcome variables weighting the nonparticipants in the program by propensity score of participants in the program. A standard cross-section estimator can be specified following way in equation (4):

$$
A T E_{p s m}=E_{p(X) / T=1}\left\{E\left[Y^{T} \mid T=1, P(X)\right]-E\left[Y^{C} \mid T=0, P(X)\right]\right\}
$$

However within the common support for cross-sectional data, the treatment effect can be written as follows in equation (5) as mention by Heckman, Ichimura, and Todd (1997) and Khandker et al. (2009).

$$
A T E_{P S M}=\frac{\left[\sum_{i \in T} \mathrm{Y}_{i}^{T}-\sum_{j \in C} \omega(i, j) \mathrm{Y}_{j}^{C}\right]}{\mathrm{N}_{T}}
$$

Where $\mathrm{N}_{T}$ is the number of participants $i$ and $\omega(i, j)$ is the weight used to aggregate outcomes for the matched nonparticipants $j$. After proper matching, biasness is removed $(\mathrm{B}=0)$. Then $\mathrm{D}=\mathrm{ATE}$ is found (Khandker et al., 2009).

The PSM method has been applied to assess the program impact in different countries. For instant, Abebaw, Fenti, and Kassa (2010) evaluated the impact of a food security program on household consumption in the Northwester Ethiopia. Raza and Ara (2012) estimated the Challenging the Frontires of Poverty Reduction (CFPR) program impact on beneficiary households' livelihoods in Bangladesh. Jalan and Ravallion (2003) assessed the effect on benefit incidence of an anti-poverty program in Argentina. Mendola (2007) calculated the impact of agricultural technology adoption on poverty reduction in Bangladesh. Hope (2007) applied PSM method to estimate the social impacts on a watershed development program in India.

To calculate the VGD program effect, the samples of beneficiary and non-beneficiary groups were pooled. Then by fitting logit model in terms of common variables as shown in Table 1, an individual household probability to be included in the VGD program was estimated. Common characteristics of households were considered as explanatory variables, in another way intervening variables, presented in Table 2. After the participation equation estimation, the predicted values of the probability of participation $\mathrm{T}$ were calculated. The predicted results signify the estimated probability to the program or propensity score. Subsequently, the common support region was defined where the distributions of the propensity score for participant and nonparticipant groups overlapped. If nonparticipant observations fall outside the common support region, they are dropped. Then special matching criteria applied to assign program participants to nonparticipants based on estimated propensity score.
Hence, it is required to calculate a weight for every matched participant-nonparticipant group. There are several methods to assign weight such as Nearest-neighbour matching (NNM), radius matching (RM), stratified matching (SM), kernel matching (KM). In the NNM, each participant is matched to the nonparticipant with the nearest propensity score as measured by the absolute difference in score. The $\mathrm{RM}$ imposes a threshold on the maximum propensity score distance. The SM divides the common support into different strata and estimates the impact of a program within each stratum. A weighted mean of these strata impact estimates comply the overall program impact. The KM employs a weighted average of every non-participant to make the counterfactual match for every participant. However, to compare the results across alternatives matching methods may reveal whether the estimated program effect is robust. Finally, ATE were estimated as the mean difference in outcomes over the common support, weighting the nonparticipants by the propensity score distribution of the program beneficiaries as shown in equation (5).

\begin{tabular}{|c|c|c|}
\hline Variable & Types and Definition & Measurement \\
\hline \multicolumn{3}{|l|}{$\begin{array}{c}\text { Dependent } \\
\text { variable }\end{array}$} \\
\hline Treatment & $\begin{array}{l}\text { Dummy, participation in } \\
\text { VGD program }\end{array}$ & 1 if yes, 0 otherwise \\
\hline \multicolumn{3}{|l|}{$\begin{array}{l}\text { Independent } \\
\text { variables }\end{array}$} \\
\hline Age & $\begin{array}{l}\text { Continuous, age of } \\
\text { household head }\end{array}$ & Years completed \\
\hline Member & Continuous, family size & $\begin{array}{l}\text { Number of household } \\
\text { members }\end{array}$ \\
\hline Land & $\begin{array}{l}\text { Continuous, land } \\
\text { holding by the } \\
\text { household }\end{array}$ & Decimal \\
\hline Mdisable & $\begin{array}{l}\text { Dummy, married with } \\
\text { disable husband }\end{array}$ & $\begin{array}{l}1 \text { if disable husband, } \\
0 \text { otherwise }\end{array}$ \\
\hline Widowed & $\begin{array}{l}\text { Dummy, household } \\
\text { head widowed }\end{array}$ & $\begin{array}{l}1 \text { if widowed, } 0 \\
\text { otherwise }\end{array}$ \\
\hline Deserted & $\begin{array}{l}\text { Dummy, household } \\
\text { head deserted }\end{array}$ & $\begin{array}{l}1 \text { if deserted, } 0 \\
\text { otherwise }\end{array}$ \\
\hline Divorced & $\begin{array}{l}\text { Dummy, household } \\
\text { head divorced }\end{array}$ & $\begin{array}{l}1 \text { if divorced, } 0 \\
\text { otherwise }\end{array}$ \\
\hline Unmarried & $\begin{array}{l}\text { Dummy, household } \\
\text { head unmarried }\end{array}$ & $\begin{array}{l}1 \text { if unmarried, } 0 \\
\text { otherwise }\end{array}$ \\
\hline Housing & $\begin{array}{l}\text { Dummy, living } \\
\text { condition }\end{array}$ & $\begin{array}{c}1 \text { if live in own house, } \\
0 \text { otherwise }\end{array}$ \\
\hline
\end{tabular}

Table 2. Notation, Name and Description of Explanatory Variables

Maintaining the above mentioned way, particularly in equation (5), ATE for protection such as per capita expenditure, food expenditure, non-food expenditure were estimated. For the promotion effect, net savings, asset creation such as durable and productive, petty investment were calculated. Average difference of probability being poor between beneficiary and non-beneficiary households was estimated as recommended by Angrist (2001). Descriptive statistics were applied to analysis child schooling for both groups. 


\section{Results and Discussion}

\section{Description of Sample Households' Characteristics}

Descriptive statistics for VGD beneficiary and non-beneficiary surveyed households are presented in Table 3 based on the pre-intervention characteristics. The head of household were young and average age of household head is about 37 years, with average age of household head of the program participant and non-participant at 36.91 and 37.06 years, respectively.

Considering the household size, family member of beneficiary is higher than non-beneficiary and the difference in mean of member is significant at 1 percent level $(t=$ -6.201). Moreover, intervening criterion for participation to the program such as widowed, divorced, vulnerable unmarried women are same to the both groups. The main differences between the two groups of households were observed with respect to land size, married with disable husband, deserted, and housing condition. Average area of land holding by the beneficiary and non-beneficiary is 3.32 and 2.33 decimal respectively. This result is statistically significance at 1 percent level $(t=-4.497)$. Though the mean difference is significant, area of land holding is very small. This means that both groups are eligible for getting benefit in terms of land holding criterion. The mean value of married with disable husband among beneficiary and non-beneficiary is 0.449 and 0.257 respectively. The mean difference is also significant at 1 percent level $(t=-3.628)$. This difference implies that the number of eligible household based on this criterion will be a smaller amount after selecting for a program cycle in a particular area. For detail of the Table-3 please see Appendix-1.

\section{PSM Estimation}

To quantify the impact of VGD program, beneficiary and non-beneficiary household were polled. Then participation into program was estimated by using logit model in order to estimate the propensity score. This score implies the probability to be included in VGD program. The estimated propensity score is required to indicate the covariates are exogenous and unaffected by the program. Selection criterions for the program are considered to ensure this condition. As the targeted group were poor commonly woman, gender criterion was not considered here. Other resources such as durable, nondurable, productive asset were not considered because program objective was to increase these assets, income, and expenditure. In Table 4, the estimated results of logit model are presented. The estimated results show the significantly influence to be participated in the program with expected sign of coefficients to the key variables.

Table 4. Logit Results of Household Participation in the Program

\begin{tabular}{|c|c|c|c|c|c|c|}
\hline Variable & Coefficient & Std.error & z-value & $\mathrm{p}>|\mathrm{z}|$ & \multicolumn{2}{|c|}{$\begin{array}{l}\text { [95\% confidence } \\
\text { interval] }\end{array}$} \\
\hline Age & -0.039 & 0.024 & -1.58 & 0.11 & -0.0878 & 0.0095 \\
\hline Member & $0.461^{* * *}$ & 0.129 & 3.56 & 0.00 & 0.2074 & 0.7147 \\
\hline Land & 0.074 & 0.083 & 0.90 & 0.36 & -0.087 & 0.2372 \\
\hline Mdisable & $16.835^{* * *}$ & 1.045 & 16.10 & 0.00 & 14.786 & 18.883 \\
\hline Widowed & $16.810^{* * *}$ & 1.050 & 16.01 & 0.00 & 14.752 & 18.868 \\
\hline Deserted & $15.444^{* * *}$ & 0.974 & 15.84 & 0.00 & 13.533 & 17.355 \\
\hline Divorced & $16.098^{* * *}$ & 0.989 & 16.27 & 0.00 & 14.159 & 18.037 \\
\hline Unmaried & $17.022^{* * *}$ & 0.986 & 17.25 & 0.00 & 15.088 & 18.957 \\
\hline Housing & $0.814^{* *}$ & 0.349 & 2.33 & 0.02 & 0.130 & 1.499 \\
\hline Constant & $-7.882^{* * * *}$ & 0.947 & -17.3 & 0.00 & -14.09 & 19.087 \\
\hline \multicolumn{7}{|c|}{ 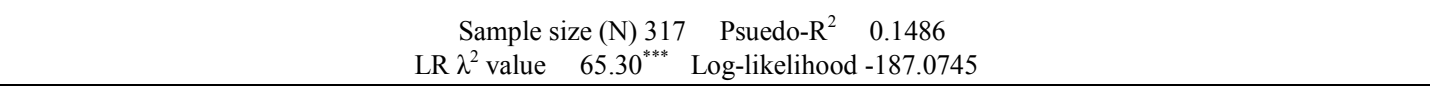 } \\
\hline
\end{tabular}

Note: * ** and *** indicated significant at $10 \%, 5 \%$ and $1 \%$ level, respectively 
The estimated propensity scores using the logit model vary between 0.0503 and $0.8164($ mean $=0.4065)$ for VGD non-beneficiary and between 0.0728 and 0.9299 (mean = $0.5935)$ for beneficiary households. The region of common support has been selected between 0.0728 - 0.9299. After imposing common support condition, a small number of non-beneficiary households have been excluded (2 households). Moreover, the quality of estimated score of matching can be evaluated by visual assessment. Histograms of estimated propensity scores for VGD beneficiary (treated) and non-beneficiary (untreated) are presented in Figure 1. Figure 1 shows the distributions of the estimated propensity scores for beneficiaries' households skewed to the right and non-beneficiaries to the left. Therefore, region of common support was larger enough. That indicates both groups are comparable on the basis of estimated propensity score.

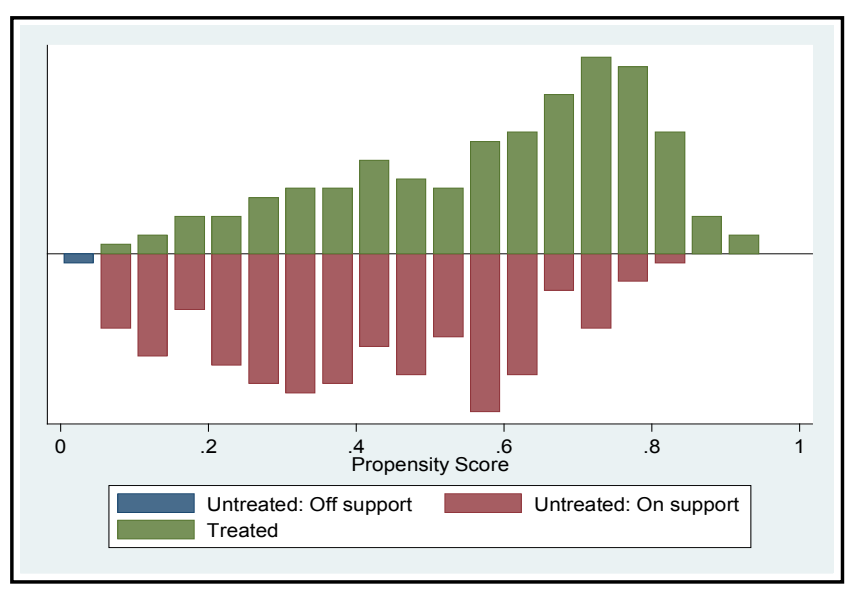

Figure 1. Propensity Score Distribution after Matching within Common Support

\section{Protection Effect}

The estimated result presented in Table 5 shows that VGD program has a positive contribution to increase household expenditure. Using the Nearest-neighbour method (NNM) and the Kernal Matching (KM) technique, the program raised per capita expenditure for the beneficiary household by 8 percent monthly which are statistically significant as shown in Table 5. Similarly, using the Stratified Matching (SM) and the Radius Matching (RM) methods the program impact on per capita expenditure was 9 percent. These results are also statistically significant. By dividing the per capita expenditure into per capita food and non-food expenditure, the study found that the program impact on per capita food expenditure decreased by 4 percent applying NNM, SM, RM, and $\mathrm{KM}$ method. On the other hand, per capita non-food expenditure increased by more than 70 percent as shown in Table 5 . These results indicate as the program beneficiaries were receiving in-kind transfer monthly, the program helps the beneficiary households to improve food deficiency and move to non-food items. On an average, about 72percent and 78 percent of per capita household expenditures are spent on food by the beneficiary and non-beneficiary, respectively.
Ahmed (1993) also found that 75 percent of per capita expenditures were spent on food by the beneficiary. As the proportion of expenditure by beneficiary devoted to food fell, it might happen because of increasing income (Haughton \& Khandker, 2009). This consumption behaviour of the households indicates that the well-known Engel' law works well.

Table 5. The VGD Program Effect on Household

\begin{tabular}{|c|c|c|c|c|}
\hline $\begin{array}{c}\text { Outcome } \\
\text { Variable }(\ln )\end{array}$ & NNM & SM & $\mathrm{RM}(.01)$ & $\begin{array}{c}\mathrm{KM} \\
\operatorname{rep}(100)\end{array}$ \\
\hline \multicolumn{5}{|l|}{$\begin{array}{c}\text { Protection } \\
\text { Effect }\end{array}$} \\
\hline $\begin{array}{l}\text { Per capita } \\
\text { household } \\
\text { expenditure }\end{array}$ & $\begin{array}{c}0.08^{* * * *} \\
(7.24)\end{array}$ & $\begin{array}{c}0.09^{* * *} \\
(12.69)\end{array}$ & $\begin{array}{l}0.09^{* * *} \\
(12.25)\end{array}$ & $\begin{array}{r}0.08^{* * * *} \\
(10.86)\end{array}$ \\
\hline $\begin{array}{c}\text { food } \\
\text { expenditure }\end{array}$ & $\begin{array}{l}-0.04^{* * *} \\
(-3.73)\end{array}$ & $\begin{array}{c}-0.04 * * * \\
(-7.02)\end{array}$ & $\begin{array}{c}-0.04 * * * \\
(-6.50)\end{array}$ & $\begin{array}{c}-0.04 * * * \\
(-7.44)\end{array}$ \\
\hline $\begin{array}{c}\text { non-food } \\
\text { expenditure }\end{array}$ & $\begin{array}{c}0.70^{* * * *} \\
(15.44) \\
\end{array}$ & $\begin{array}{l}0.72 * * * \\
(28.60)\end{array}$ & $\begin{array}{l}0.72 * * * \\
(25.41) \\
\end{array}$ & $\begin{array}{r}0.72 * * * \\
(33.97) \\
\end{array}$ \\
\hline \multicolumn{5}{|l|}{$\begin{array}{c}\text { Promotion } \\
\text { Effect }\end{array}$} \\
\hline HH Savings & $\begin{array}{l}6.08 * * * \\
(11.78)\end{array}$ & $\begin{array}{l}5.95 * * * \\
(16.06)\end{array}$ & $\begin{array}{l}5.84 * * * \\
(24.37)\end{array}$ & $\begin{array}{l}5.99 * * * \\
(21.71)\end{array}$ \\
\hline $\begin{array}{l}\text { HH Durable } \\
\text { goods }\end{array}$ & $\begin{array}{l}1.32 * * \\
(2.43)\end{array}$ & $\begin{array}{c}1.02 * * * \\
(5.18)\end{array}$ & $\begin{array}{c}1.40^{* * *} \\
(5.46)\end{array}$ & $\begin{array}{c}1.11^{* * * *} \\
(5.59)\end{array}$ \\
\hline $\begin{array}{c}\mathrm{HH} \\
\text { productive } \\
\text { assets }\end{array}$ & $\begin{array}{l}2.07 * * \\
(2.78)\end{array}$ & $\begin{array}{c}3.05^{* * *} \\
(5.18)\end{array}$ & $\begin{array}{c}2.65^{* * *} \\
(5.73)\end{array}$ & $\begin{array}{c}3.01 * * * \\
(7.44)\end{array}$ \\
\hline \multicolumn{5}{|l|}{$\begin{array}{c}\text { Effect on } \\
\text { poverty }\end{array}$} \\
\hline HH poverty & $\begin{array}{c}-0.33 * * * \\
(-5.93)\end{array}$ & $\begin{array}{c}-0.35^{* * *} \\
(-9.69)\end{array}$ & $\begin{array}{c}-0.41 * * * \\
(-8.64) \\
\end{array}$ & $\begin{array}{c}-0.35^{* * * *} \\
(-9.41)\end{array}$ \\
\hline $\begin{array}{l}\text { Balancing } \\
\text { property }\end{array}$ & Yes & Yes & Yes & Yes \\
\hline $\begin{array}{c}\text { Common } \\
\text { support } \\
\text { imposed } \\
\text { Number of } \\
\text { observation: }\end{array}$ & Yes & Yes & Yes & Yes \\
\hline $\begin{array}{c}\text { VGD } \\
\text { beneficiary } \\
\text { VGD }\end{array}$ & 157 & 157 & 129 & 157 \\
\hline $\begin{array}{c}\text { non-beneficiar } \\
\text { y }\end{array}$ & 77 & 157 & 151 & 157 \\
\hline
\end{tabular}

Note: $\mathrm{NNM}=$ Nearest-Neighbour Matching, $\mathrm{SM}=$ Stratification Matching, $\mathrm{RM}=$ Radius Matching, $\mathrm{KM}=$ Kernel Matching. *, ** and $* * *$ indicated significant at $10 \%, 5 \%$ and $1 \%$ level, respectively. t- value in the parenthesis.

\section{Promotion Effect}

Among the non-beneficiary, only 18 percent of households had a tendency to save. The amount of average savings was BDT1562 and BDT111 among beneficiary and non-beneficiary households, respectively. Rahman and Choudhury (2012) found average amount of saving by the beneficiary household was BDT1536 after the benefit cycle. Using PSM method, the study found that saving of beneficiary households increased by minimum 584 percent using RM and maximum 608 percent using NNM method, which are statistically significant. Ahmed et al. (2009) also found that the average amount of saving increased by 512 
percent for beneficiary households.

About 40 percent and 38 percent of beneficiary households said they saved for their children educational expenses and petty investment, respectively. These imply that beneficiary household was motivated to save for overcoming the impediment of child education expenses and for generating income. Both might be helpful to eradicate poverty persistently in the future.

The results show that the program impact on the value of durable goods increased by more than 100 percent by applying the various matching methods presented in Table 5 . This change is not incredible because any positive shock has a large tendency to increase spending on durable goods (Monacelli, 2009). Moreover, mobile phone and sewing machine are used to increase the household's income generating activities. For example, anyone can communicate with the household members who work in construction and others as the use of mobile phone increased extensively at all level of people (Hasan, Yeasmin, \& Dey, 2013).

Among the rural poor, livestock and poultry are more important productive assets (Ahmed et al., 2009). The study found that the value of the productive assets increased among the program participants by 200 per cent to 300 per cent as shown in Table 5. Ahmed et al. (2009) found that average value of productive assets increased by 96 percent for beneficiary households compared with their match control groups. This study included poultry and livestock together as productive assets, while Ahmed et al. (2009) considered only livestock as productive assets. Consequently, this study finding shows the program impact on productive assets is more significant.

Petty trading is a part of informal sector activities that employ the poor people in developing countries. This trading is conducted in small scale, basically low-priced items. This study found that only 24 households are involved in petty trading among survey participants. Among them, 21 households were beneficiary ( 42 percent of the beneficiary). Average monthly income of the beneficiary from petty trading than non-beneficiary is about BDT463. This income is about 35 percent of beneficiary per capita household expenditure despite it is a little amount.

The benefit transfer also helps to keep the children in school. From the survey data the study found that about 52 percent of the VGD beneficiary households sent their children to school, while this rate was 23 percent among non-beneficiary households. Child working rate was also less among beneficiary ( 3 percent) than non-beneficiary ( 7 percent) households. In terms of child numbers, school attendance rate is 79.68 percent of total children among non-beneficiary while only 33.56 percent among non-beneficiary. On the contrary, child working rate is high among non-beneficiary (37.02 percent) than beneficiary households ( 9.68 percent).

\section{Effect on Poverty}

It is generally believed that the gender of the household head influences significantly the household poverty. Consequently, female headed households are poorer than male headed household (Haughton \& Khandker, 2009). The government has introduced the VGD program for female head household on a priority basis expecting to lessen the poverty rate. The different quantitative indicators show that beneficiary households improve their wellbeing significantly as expected using PSM method. The qualitative indicators also point out the same results. Accordingly, the matching procedure applied to estimate the probability of the household to be poor. The NNM and RM show that the beneficiaries are less likely to be poor around 33 percent and 41 percent points on an average which are significant. But SM and KM show that probability to be poverty is reduced by 35 percent point which is significant at 5 percent level, respectively. These results imply that VGD program benefit package promoted the beneficiary households wellbeing and productive capacity that reduced the probability to be poor.

\section{Conclusion and Policy Recommendation}

The main purpose of this study was to review and evaluate the impact of VGD program on household welfare using cross-sectional survey data from Sylhet District in Bangladesh. The estimated results show that VGD program has raised per capita expenditure significantly among the beneficiary households. Interestingly, the study has found that per capita food expenditure among the beneficiary was lower than the non-beneficiary. But in case of per capita non-food expenditure, the results were reverse. These results indicate that VGD program helps decrease food deficit and increase food diversity among the beneficiary households. It is apparent from the study finding that the program has a clear success on protection goal among beneficiary households. Moreover, the beneficiary households were in better off condition in terms of savings, durable goods, productive assets, and involvement in petty trading. In addition, rate of child schooling among the beneficiary was higher than the non-beneficiary households.

The study findings show that the program had protective goal among the beneficiary households. As the beneficiary were young and received training, protective outcomes also extended to promotional effect. But it is less clear from the field survey whether the beneficiary households had persistence income sources. Moreover, the study findings provide essential massages for policy makers. The findings provide evidence that VGD program played vital role to protect and promote household's wellbeing. This suggests that policy makers can maximize the impact by continuing the support and extending for others who are eligible for the program. 


\section{Appendix-1}

Table 3. Characteristics of Sample Households Based on Pre-Intervention Criterion

\begin{tabular}{cccccccccc}
\hline \multirow{2}{*}{ Variables } & \multicolumn{2}{c}{ Sample households } & \multicolumn{2}{c}{ Beneficiary households } & \multicolumn{2}{c}{ Non-beneficiary } & \multicolumn{3}{c}{ Difference in means } \\
\cline { 2 - 8 } & Mean & std.dev & Mean & std.dev & Mean & std.dev & \multicolumn{2}{c}{ Mean } & std.err \\
\hline Age & 36.99 & 6.174 & 36.91 & 6.70 & 37.06 & 5.618 & 0.168 & 0.694 & 0.227 \\
Member & 4.16 & 1.208 & 4.56 & 1.238 & 3.76 & 1.038 & 0.795 & -0.128 & $-6.201^{* * *}$ \\
Land & 2.82 & 2.023 & 3.32 & 1.977 & 2.33 & 1.951 & 0.992 & -0.220 & $-4.497^{* * *}$ \\
Mardisab & 0.353 & 0.478 & 0.449 & 0.499 & 0.257 & 0.438 & 0.191 & -0.052 & $-3.628^{* * *}$ \\
Widowed & 0.407 & 0.492 & 0.392 & 0.489 & 0.421 & 0.495 & 0.029 & 0.055 & -0.523 \\
Deserted & 0.126 & 0.332 & 0.056 & 0.232 & 0.194 & 0.397 & 0.138 & -0.036 & $3.770^{* * *}$ \\
Divorced & 0.066 & 0.249 & 0.044 & 0.206 & 0.088 & 0.284 & 0.043 & -0.028 & 1.56 \\
Unmarried & 0.044 & 0.205 & 0.056 & 0.232 & 0.031 & 0.175 & 0.025 & -0.031 & -1.104 \\
Housing & 0.697 & 0.461 & 0.829 & 0.377 & 0.566 & 0.497 & 0.263 & -0.049 & $-5.302^{* * *}$ \\
\hline
\end{tabular}

Note: $* * *$ and $* * *$ indicated significant at $10 \%, 5 \%$ and $1 \%$ level, respectively

\section{REFERENCES}

Abebaw, D., Fentie, Y., \& Kassa, B. (2010). The impact of a food security program on household food consumption in Northwestern Ethiopia: A matching estimator approach. Food Policy, 35(4), 286-293.

Ahmed, A. U. (1993). Food consumption and nutritional effects of targeted food interventions in Bangladesh. Dhaka: International Food Polley Research Institute, Bangladesh Food Polley Project.

Ahmed, A. U., Quisumbing, A. R., Nasreen, M., Hoddinott, J. F., \& Bryan, E. (2009). Comparing food and cash transfers to the ultra poor in Bangladesh: International Food Policy Research Institute.

Angrist, J.D., 2001. Estimation of limited dependent variable models with dummy endogenous regressors. J. Bus. Econ. Stat., 19: 2-28. Doi: 10.1198/07350010152472571 BBS. (2010). Preliminary Report on Household Icome \& Expenditure Survey: Statistics Division, Ministry of Planning, The Government of the People's Republic of Bangladesh.

BBS. (2011). Population and Housing Sensus 2011:Preliminary Results. Dhaka: Bangladesh Bureau of Statistics(BBS).Devereux, S. (2002). Can social safety nets reduce chronic poverty? Development Policy Review, 20(5), 657-675.

Galasso, E., \& Ravallion, M. (2005). Decentralized targeting of an antipoverty program. Journal of Public Economics, 89(4), 705-727.

Gimenez, L., Ahmed, F., Sharif, I., \& Jolliffe, D. (2013). Bangladesh Poverty Assessment: A Decade of Progress in Reducing Poverty, 2000-2010 Bangladesh development series ; paper no. 31. . Washington DC: World Bank.

Grosh, M. E., Del Ninno, C., \& Tesliuc, E. (2008). For Protection and Promotion : The Design and Implementation of Effective Safety Nets. Herndon, VA, USA: World Bank Publications.

Hasan, M. K., Yeasmin, A., \& Dey, P. (2013). Factors Influencing to Bangladeshi Consumers' Mobile Phone Operators Choice and
Change Behavior. Journal of Economics and Sustainable Development, 4(2), 159-169.

Haughton, J., \& Khandker, S. R. (2009). Handbook on poverty and inequality. Washingon, DC: World Bank Publications.Heckman, J. J., Ichimura, H., \& Todd, P. (1998). Matching as an econometric evaluation estimator. The Review of Economic Studies, 65(2), 261-294.

Heckman, J. J., Ichimura, H., \& Todd, P. E. (1997). Matching as an econometric evaluation estimator: Evidence from evaluating a job training programme. The Review of Economic Studies, 605-654.

Heckman, J. J., LaLonde, R. J., \& Smith, J. A. (1999). The economics and econometrics of active labor market programs. Handbook of labor economics, 3, 1865-2097.

Hope, R. (2007). Evaluating social impacts of watershed development in India. World Development, 35(8), 1436-1449.

Jalan, J., \& Ravallion, M. (2003). Estimating the benefit incidence of an antipoverty program by propensity-score matching. Journal of Business and Economic Statistics, 21(1), 19-30.

Jalan, J., \& Ravallion, M. (2003). Estimating the benefit incidence of an antipoverty program by propensity-score matching. Journal of Business \& Economic Statistics, 21(1), 19-30.

Khan, Z., Sulaiman, J., Ibrahim, M., \& Hussain Shah, W. (2013). Social Safety Nets and Sustainable Economic Development: A Theoretical Perspective with Reference to Pakistan Economy. Dialogue, 8(2), 1819-6462.

Khandker, S. R., Koolwal, G. B., \& Samad, H. A. (2009). Handbook on impact evaluation: quantitative methods and practices: World Bank Publications.

Low, J. W., Garrett, J. L., \& Ginja, V. (1999). Can Cash Transfer Programs Work in Resource Poor Countries? The Experience of Mozambique FCND Discussion no 270: IFPRI.

Mendola, M. (2007). Agricultural technology adoption and poverty reduction: A propensity-score matching analysis for rural Bangladesh. Food Policy, 32(3), 372-393.

Monacelli, T. (2009). New Keynesian models, durable goods, and 
collateral constraints. Journal of Monetary Economics, 56(2), 242-254.

Rahman, H. Z., \& Choudhury, L. A. (2012). Social Safety Nets in Bangladesh (Vol. 2). Dhaka: Power and Participation Research Centre.

Ravallion, M. (2007). Evaluating anti-poverty programs. Handbook of development economics, 4, 3787-3846.Ravallion, M., Van de Walle, D., \& Gautam, M. (1995). Testing a social safety net. Journal of Public Economics, 57(2), 175-199.
Raza, W., \& Ara, J. (2012). Grant Based Approach to Poverty Reduction: Evidence from Bangladesh. OIDA International Journal of Sustainable Development, 3(6), 37-56.

Rosenbaum, P. R., \& Rubin, D. B. (1983). The central role of the propensity score in observational studies for causal effects. Biometrika, 70(1), 41-55.

Vlachantoni, A., \& Falkingham, J. (2012). Gender and Old-Age Pension Protection in Asia. In S. W. Handayani \& B. Babajanian (Eds.), Social Protection for Older Persons (pp. 120-134): Asian Development Bank. 